\title{
DESENTRALISASI PENDIDIKAN DI INDONESIA: KORUPSI DAN PROBLEM POLITIK KEKUASAAN
}

\author{
FATKHURI \\ Dosen Tetap Program Studi IImu Politik \\ Fakultas Ilmu Sosial dan Ilmu Politik \\ Universitas Pembangunan Nasional "Veteran" Jakarta \\ fatkhuri@upnvj.ac.id
}

\begin{abstract}
Since the emergence of Indonesian reforms, Education sector has become an issue which is widelly discussed by many people. This issue ranks at the top, along with the issues of economic welfare and health. Some people said education in Indonesia is lagging behind. This is the condition that demands encouragement to the government to be more serious in paying attention to the expansion of access and quality improvement in education. This study attempts to deeply grasp the problem of decentralization in education in the regions. Since regional autonomy is enacted, education is one of the matters whose authorities are delegated by the central government to local governments. The results of this study describe the decentralization of education has not had an impact on the expansion of access and improving the quality of education. This phenomenon occurs for two reasons. First, decentralization has broaden a space for local elites to make a corruption problem. Decentralization that actually should be utilized to provide educational services, has been diverted into the condition in which State Expenditure Budget (APBN) funds are robbed. Secondly, the decentralization of education has not yet touched on the substance of education itself, due to the strength of the political grip of the rulers at the local level. Due to elite political clutches, the role of educational institutions both schools and educational quality assurance institutions in the region to be less effective.
\end{abstract}

Keywords: Decentralization; Education; Politics

\begin{abstract}
ABSTRAK
Sejak reformasi bergulir, isu Pendidikan menjadi perbincangan hampir di semua segmen masyarakat. Isu ini menempati urutan teratas, sejajar dengan isu kesejahteraan ekonomi dan kesehatan. Banyak kalangan menilai, pendidikan di negara Indonesia tertinggal. Kondisi inilah yang menuntut adanya dorongan kepada pemerintah agar lebih serius dalam memerhatikan perluasan akses dan peningkatan mutu di dunia Pendidikan. Studi ini menggali lebih dalam problem desentralisasi pendidikan di daerah. Sejak otonomi daerah diberlakukan, pendidikan merupakan salah satu urusan yang wewenangnya dilimpahkan oleh pemerintah pusat kepada pemerintah daerah. Hasil kajian ini menguraikan desentralisasi pendidikan belum memberikan dampak terhadap perluasan akses dan peningkatan mutu pendidikan. Fenomena ini terjadi karena dua alasan. Pertama, desentralisasi telah menjadi
\end{abstract}


ruang bagi elit-elit di daerah untuk melakukan korupsi. Desentralisasi yang semestinya dapat dimanfaatkan untuk memberikan pelayanan pendidikan, telah dibelokan menjadi ajang mengeruk kekayaan melalui dana APBN yang diperuntukkan untuk daerah. Kedua, desentralisasi pendidikan belum menyentuh pada tataran substansi masalah untuk membangun pendidikan yang sesungguhnya karena kuatnya cengkeraman politik penguasa di tingkat lokal. Akibat cengkeraman politik elit, peran serta lembaga pendidikan baik Sekolah maupun lembaga penjaminan mutu pendidikan di daerah menjadi kurang efektif.

\section{Kata Kunci: Desentralisasi; Pendidikan; Politik.}

\section{Pendahuluan}

Sejak reformasi bergulir, isu Pendidikan menjadi perbincangan hampir di semua segmen masyarakat. Isu ini menempati urutan teratas, sejajar dengan isu kesejahteraan ekonomi dan kesehatan. Yang dimaksud dengan "Pendidikan" dalam studi ini dibatasi pada bidang Pendidikan Dasar dan Menengah. Sejak era Otonomi Daerah, bidang Pendidikan Dasar dan Menengah termasuk urusan yang didesentralisasikan dari Pemerintah Pusat ke Pemerintah Daerah. Setelah pelaksanaan otonomi pendidikan, maka pengelolaan pendidikan tidak lagi tersentralisasi, sehingga peran pemerintah daerah untuk memajukan pendidikannya menjadi sangat terbuka (Purwanto, 2008).

Pendidikan merupakan isu strategis yang berkaitan langsung dengan kebutuhan rakyat, seperti halnya kesejahteraan ekonomi dan kesehatan. Tidak jarang, dalam setiap pemilihan pemimpin politik, baik di tingkat pusat maupun daerah, hampir dipastikan isu pendidikan selalu menyertainya. Pendidikan khususnya pendidikan formal disekolah merupakan tempat transfer pengetahuan tetapi juga sebagai tempat transfer nilai, nilai dalam hal ini sangat erat kaitannya dengan norma-norma dan segala sesuatu yang baik dimasyarakat (Purwanto, 2008). Dengan sangat strategisnya isu Pendidikan, banyak pihak-pihak terkait seperti politisi menggunakannya sebagai "political branding" dalam kontestasi perebutan kekuasaan. Dalam perspektif politik lokal, isu pendidikan gratis acapkali menjadi jurus kampanye politik setiap pasangan calon yang maju dalam pemilihan kepala daerah (Pilkada). Isu pendidikan diyakini memiliki daya tarik tersendiri bagi para kandidat yang maju dalam pilkada. Oleh karena itu, isu ini menjadi barang dagangan yang laris dalam ajang kontestasi 5 (lima) tahunan tersebut. 
Politisasi pendidikan yang semakin marak ini mengundang keprihatinan para pihak yang selama ini lebih concern terhadap subtansi pendidikan, yaitu meningkatkan mutu pendidikan. Muhadjir Effendi selaku Menteri Pendidikan dan Kebudayaan (Mendikbud) mengkritik para politisi yang menjadikan isu pendidikan hanya sebatas sebagai komoditas politik saat Pilkada. Menurutnya, isu sekolah gratis tak lebih menjadi komoditas yang justru merusak pendidikan itu sendiri. Hal ini disebabkan karena minimnya peran kepala daerah setelah terpilih dalam mengupayakan peningkatan kualitas pendidikan. Menurutnya, berdasarkan data yang dimiliki hanya di DKI Jakarta yang pendidikan gratisnya terjamin, dimana dengan total anggaran APBD DKI 2017 sebesar 70 triliun, 22,3 persen telah dialokasikan untuk pendidikan. Sebaliknya, Mendikbud menyebut anggaran pendidikan di beberapa provinsi masih di bawah 20 persen, seperti Kalimantan Selatan, yang hanya mengalokasikan APBD sebesar 9 persen (http://news.metrotvnews.com). Kritik serupa dilontarkan Wakil Ketua Komisi $X$ DPR RI Abdullah Fikri, yang mengusulkan agar isu pendidikan tidak dijadikan jargon-jargon kampanye para calon kepala daerah menjelang Pilkada Serentak yang akan berlangsung di 171 daerah di seluruh Indonesia pada Juni tahun 2018, sebab yang terjadi malah jauh antara janji dan realisasi. (http://www.dpr.go.id).

Berkaitan dengan isu pendidikan, Indonesia termasuk negara yang bisa dikatakan belum memiliki prestasi menggembirakan. Beberapa kalangan menilai pendidikan di negara Indonesia sangat tertinggal jauh dari Negaranegara tentangga. Berdasarkan hasil penilaian Programme for International Student Assessment (PISA) tahun 2015, rangking Indonesia di bidang Sains 62, Matematika 63, dan Membaca 64, dari total 70 negara yang menjadi peserta (https://pisaindonesia.wordpress.com). Rendahnya pencapaian hasil penilaian PISA di atas dipicu dengan pencapaian siswa di Indonesia yang tidak memenuhi standar. Berdasarkan data, sebanyak 42 persen siswa di Indonesia yang berumur 15 tahun tidak mampu mencapai standar minimal dari 3 bidang (maple) di atas (Rosser, 2018).

Meskipun hasil ini secara umum ada perubahan positif di banding hasil penilaian pada periode sebelumnya, namun posisi Indonesia yang berada pada 10 besar dari bawah menunjukkan Indonesia mengalami masalah serius 
Fatkhuri. Desentralisasi Pendidikan... | 281

dalam bidang Pendidikan. Penting dicatat bahwa PISA merupakan sistem ujian yang diinisasi oleh Organisation for Economic Cooperation and Development (OECD), untuk mengevaluasi sistem pendidikan dari 72 negara di seluruh dunia. (https://www.kemdikbud.go.id). Penilaian PISA tahun 2015 difokuskan pada 3 bidang yaitu science, reading, dan Matematika, serta collaborative problem-solving sebagai sebuah aspek minor yang menjadi area penilaian (OECD, 2016).

Kondisi inilah yang menuntut pemerintah baik pusat maupun daerah agar lebih serius dalam memerhatikan peningkatan mutu di dunia Pendidikan, bukan sekendar menjadi komoditas politik untuk pemenuhan hasrat kekuasaan para oknum-oknum yang tidak bertanggungjawab.

Jika kita mundur sejenak, rendahnya mutu pendidikan di Indonesia telah menjadi perhatian banyak kalangan sejak reformasi bergulir. Desakan akan pentingya reformasi di bidang pendidikan inilah yang pada akhirnya melahirkan Undang-Undang Sistem Pendidikan Nasional (Sisdiknas) Nomor 20 tahun 2003. Undang-Undang ini lahir dengan semangat untuk merubah carut marut problem pendidikan di Indonesia dari mulai tata kelola sampai pada upaya melahirkan sebuah sistem percepatan peningkatan mutu pendidikan di Indonesia. Pendidikan merupakan isu sentral dan menjadi hak dasar warga negara yang tidak bisa ditunda dalam pemenuhannya. Undang-Undang Dasar 1945 secara tegas mengamanatkan dalam pembukaannya bahwa pemerintah wajib untuk berperan dalam upaya mencerdaskan kehidupan bangsa. Oleh karena itu, pemenuhan salah satu hak dasar warga negara ini dilakukan dengan melakukan usaha yang serius dan terukur dalam rangka menyelenggarakan satu sistem pendidikan nasional yang meningkatkan tidak hanya kecerdasan warga bangsa, tetapi juga keimanan dan ketakwaan masyarakat.

Hadirnya kebijakan pemerintah di bidang pendidikan disambut dengan positif oleh banyak kalangan. Harapan disematkan kepada pemerintah dimana dengan UU Sisdiknas tersebut, diharapkan dapat menciptakan sistem pendidikan nasional yang mampu menjamin pemerataan kesempatan pendidikan, peningkatan mutu serta relevansi dan efisiensi manajemen pendidikan untuk menghadapi tantangan sesuai dengan tuntutan perubahan kehidupan lokal, nasional, dan global. Oleh karena itu, dengan spirit 
reformasi, pemerintah berusaha melakukan pembaharuan pendidikan secara terencana, terarah, dan berkesinambungan. Kebijakan ini merupakan bentuk respon cepat pemerintah dalam rangka mendukung percepatan di bidang Pendidikan, yang saat itu menjadi agenda penting reformasi. Bentuk kongkrit keberpihakan pemerintah pada dunia pendidikan adalah melalui UU Nomor 20 tahun 2003 tersebut, pemerintah dan pemerintah daerah wajib mengalokasikan dana APBN dan APBD sebanyak 20 persen untuk pendidikan. Alokasi 20 persen ini juga merupakan bagian integral dari amanat hasil Amandemen ke-IV Undang-Undang Dasar 1945. Selanjutnya, pemerintah juga menerbitkan Undang-Undang Otonomi Daerah Nomor 22 tahun 1999 yang mengatur pelimpahan wewenang di bidang pendidikan dari pemerintah pusat kepada daerah. Undang-undang ini dalam perkembangannya mengalami revisi, yaitu dengan diterbitkannya UU Nomor 32 tahun 2004 tentang Pemerintah Daerah, yang belakangan telah berganti dengan diberlakukannya UU Nomor 23 tahun 2014.

Berpijak dari permasalahan di atas, bagaimana perkembangan desentralisasi pendidikan di Indonesia? Sejauhmana pemerintah daerah memiliki keberpihakan terhadap bidang pendidikan, terutama pada upaya peningkatan mutu pendidikan di daerah? Studi ini menggali lebih dalam problem desentralisasi pendidikan di daerah.

\section{Tinjauan Pustaka}

Desentralisasi adalah pelimpahan wewenang yang diberikan oleh pemerintah kepada pemerintah daerah untuk mengurus rumah tangganya sendiri. Banyak literatur menjelaskan konsep desentralisasi, yang meskipun berangkat dalam perspektif yang berbeda-beda, namun substansi konsep tersebut pada prinsipnya memiliki persamaan. Undang-Undang Nomor 32 tahun 2004 tentang Pemerintahan Daerah mendefinisikan Desentralisasi sebagai penyerahan wewenang pemerintahan oleh Pemerintah kepada daerah otonom untuk mengatur dan mengurus urusan pemerintahan dalam sistem Negara Kesatuan Republik Indonesia (Undang-Undang Nomor 32 tahun 2004 tentang Pemerintahan Daerah, bab I. Pasal 1 ayat (7). Sementara itu, dalam Undang-Undang 23 tahun 2014 tentang Pemerintahan Daerah, Desentralisasi pengertiannya adalah penyerahan Urusan Pemerintahan oleh Pemerintah 
Fatkhuri. Desentralisasi Pendidikan... | 283

Pusat kepada daerah otonom berdasarkan Asas Otonomi. Asas Otonomi maknannya adalah prinsip dasar penyelenggaraan Pemerintahan Daerah berdasarkan Otonomi Daerah (Undang-Undang Nomor 23 tahun 2014 tentang Pemerintahan Daerah, bab I. Pasal 1 ayat (7 dan 8). Terbitnya UndangUndang Nomor 23 tahun 2014 merupakan pengganti dari Undang-Undang Nomor 32 tahun 2004 tentang Pemerintahan Daerah. Pada dasarnya perubahan Undang-Undang Nomor 32 Tahun 2004 tentang Pemerintahan Daerah ditujukan untuk mendorong lebih terciptanya daya guna dan hasil guna penyelenggaraan Pemerintahan Daerah dalam menyejahterakan masyarakat, baik melalui peningkatan pelayanan publik maupun melalui peningkatan daya saing Daerah. Perubahan ini bertujuan untuk memacu sinergi dalam berbagai aspek dalam penyelenggaraan Pemerintahan Daerah dengan Pemerintah Pusat (Undang-Undang Republik Indonesia Nomor 23 Tahun 2014 Tentang Pemerintahan Daerah: 221).

Dalam Encyclopedy of Public Administration and Public Policy, desentralisasi didefinisikan sebagai tanggung jawab yang diemban oleh kepala daerah terpilih untuk memberikan layanan, mengelola, dan melaksanakan anggaran berdasarkan alokasi yang diberikan oleh pemerintah pusat. Desentralisasi merupakan bagian penting dari sebuah upaya untuk mendekatkan pelayanan terhadap warga negara. Desentralisasi dianggap sebagai jalan keluar ketika pemerintah pusat tidak dapat memberikan layanan yang efektif, sehingga pemerintah lokal merupakan solusi atas berbagai masalah yang dihadapi dalam relasi antara pemerintah pusat dan rakyat yang tidak efektif dan efisien. Keberadaan pemerintah lokal dengan wewenang yang dimiliki dinilai lebih baik daripada pemerintah pusat dalam konteks melakukan identifikasi dan mengerti kebutuhan masyarakat lokal (David Seth Jones, 2008).

Sejalan dengan konsep di atas, Bahl (2009) memberikan penekanan pada tujuan desentralisasi yang dapat menghasilkan kesejahteraan rakyat. Dalam studinya, desentralisasi dinilai merupakan pendekatan yang dianggap mampu mengangkat kesejahteraan rakyat. Dalam konteks ini, hubungan pemerintah yang merupakan pemberi layanan dengan rakyat yang dilayani semakin dekat. Kedekatan relasi antara pemerintah daerah dan rakyat memberikan dampak positif, dimana pemenuhan hak warga negara dapat 
lebih efektif, karena diberikan berdasarkan kebutuhan rakyat tersebut. Bahl (2009) menguraikan aspek positif dari desentraliasi, yakni apa yang disebutnya sebagai "welfare gain" (Bahl, 2009). Pengertian welfare gain menurut Bahl adalah bahwa desentralisasi mendekatkan berbagai layanan kepada masyarakat. Lebih jauh Bahl membuat ilustrasi bahwa pilihan masyarakat pada dasarnya beragam, didasarkan atas kepentingan agama, bahasa, etnis, alam, ekonomi atau kecenderungan/kesukaan terhadap pemimpin politik di daerah. Jika pemerintah daerah mampu merespon berdasarkan beragam kepentingan tersebut dalam struktur anggaran yang dimiliki, maka desentralisasi akan melahirkan beragam jenis layanan yang diberikan di berbagai daerah (Bahl, 2009). Selanjutnya masyarakat akan memperoleh apa yang mereka inginkan, sehingga kondisi ini pada akhirnya memberikan dampak ikutan, yaitu kesejahteraan masyarakat. Sementara ketika layanan di bawah kendali pemerintah pusat, maka jenis layanan yang diberikan lebih menekankan pada keseragaman, sehingga rakyat yang berada di daerah dengan beragam karakteristik dan kebutuhan tersebut akan kehilangan apa yang mereka inginkan (Bahl, 2009).

Sementara itu, desentralisasi pendidikan maknanya adalah pelimpahan wewenang di bidang pendidikan oleh pemerintah pusat kepada pemerintah daerah untuk mengurus dan mengelola program terkait bidang pendidikan. Dengan desentralisasi tersebut, diharapkan pemerataan akses dan mutu layanan pendidikan dapat ditingkatkan. Sebagaimana diuraikan oleh Supriyadi (2009) bahwa desentralisasi pendidikan merupakan sebuah usaha yang bertujuan untuk meningkatkan mutu layanan dan kinerja pendidikan, baik pemerataan, kualitas, relevansi dan efisiensi pendidikan. Selain itu, desentralisasi juga ditujukan untuk mengurangi beban pemerintah pusat yang berlebihan, mengurangi kemacetan-kemacetan jalur-jalur komunikasi, meningkatkan kemandirian, demokrasi, daya tanggap, akuntabilitas, kreativitas, inovasi, prakarsa, dan meningkatkan pemberdayaan dalam pengelolaan dan kepemimpinan pendidikan (Supriyadi, 2009).

Sementara itu, argumentasi mengapa desentralisasi pendidikan sangat penting untuk diterapkan dikemukakan oleh Winingsih, yang mengkaji bahwa desentralisasi pendidikan dapat menjamin Implementasi sistem pendidikan akan lebih efisien, lebih berkualitas dan berkeadilan. Hal ini terjadi karena 
kewenangan untuk mengelola pendidikan telah dilimpahkan ke daerah, sehingga sistem pendidikan akan lebih responsif terhadap kebutuhan daerah (Winingsih, tt.: 2). Lebih jauh diuraikan bahwa alasan mengapa sektor pendidikan didesentralisasikan adalah karena adanya tekanan politis, stabilitas ekonomi makro, pelayanan umum, keadilan, effisiensi, pemberantasan kemiskinan, peningkatan kapasitas, korupsi, pengelolaan, investasi infrastruktur, dan penyediaan pelayanan sosial (Winingsih, tt.:7-8). Desentralisasi pendidikan memberikan ruang yang cukup luas kepada pemerintah daerah untuk mengambil keputusan secara cepat dan partisipatif. Hal ini bisa dilihat dengan adanya dorongan untuk pengambilan keputusan berdasarkan kebutuhan nyata di lapangan, dan saat yang sama masyarakat diberikan kesempatan untuk menyampaikan aspirasi mereka. Menurut Winingsih, desentralisasi memberikan otonomi yang lebih besar kepada pemerintah daerah atau bahkan sekolah, sehingga dapat meningkatkan kinerja dan akuntabilitas Sekolah (Winingsih, tt.:19). Selanjutnya, dalam hal di mana dana pemerintah pusat terbatas, desentralisasi memperkuat otoritas dalam pengelolaam administrasi di tingkat Pemerintah, yang juga akan mendorong bagaimana sumber daya pendidikan digali dan digunakan (Winingsih, tt: 19).

Dari berbagai uraian tersebut, benang merah dari desentralisasi pada prinsipnya adalah bentuk pelimpahan wewenang yang diberikan pemerintah dalam rangka meningkatkan efektifitas dan efisiensi layanan pendidikan kepada masyarakat. Desentralisasi merupakan anti-tesis dari realitas birokrasi yang panjang (red-tape), yang tidak dapat menjangkau kebutuhan masyarakat yang ada di daerah. Desentralisasi memangkas jarak layanan menjadi semakin dekat dengan rakyat. Desentralisasi pendidikan menjadikan pemerataan akses dan mutu pendidikan dapat ditingkatkan. Dengan demikian, masyarakat akan lebih memperoleh benefit, sehingga mampu mendorong tingkat keberdayaan mereka yang muaranya adalah pada peningkatan kesejahteraan warga (welfare gain).

Dalam konteks pendidikan, desentralisasi dapat dilihat dari beberapa aspek sebagai berikut:

1. mendekatkan pelayanan publik pendidikan terhadap rakyat; 
286 | Fatkhuri. Desentralisasi Pendidikan...

2. memberikan otoritas penuh kepada pemerintah daerah bahkan Sekolah/Madrasah untuk mendayagunakan segala sumber daya yang dimiliki untuk kepentingan peningkatan mutu pendidikan;

3. memberikan ruang bagi masyarakat untuk ikut berpartisipasi dalam proses pembangunan pendidikan;

4. menciptakan keadilan; dan

5. mendorong kesejahteraan rakyat.

\section{Metode Penelitian}

Metode Penelitian yang digunakan dalam studi ini adalah menggunakan Studi Kualitatif melalui kajian pustaka/dokumen. Studi/kajian pustaka merupakan metode dalam sebuah studi yang menggunakan berbagai sumber kredibel untuk digunakan sebagai obyek studi. Studi dokumen ini dilakukan dengan melakukan telaah dokumen baik dari dokumen pribadi maupun publik seperti: notulen, surat kabar, jurnal pribadi, diare, dan surat (Phyllis Tharenou, dkk. 2007). Dalam kajian ini, Penulis menginventarisir berbagai sumber baik dari buku, jurnal, informasi dari internet, dan Peraturan-Peraturan terkait. Berbagai informasi dari referensi yang relevan tersebut kemudian dilakukan reviu dan dianalisis.

\section{Desentralisasi Pendidikan dan masalah Korupsi}

Sebagaimana diuraikan di atas, desentralisasi pada prinsipnya adalah transfer kewenangan. Dengan desentralisasi, pemerintah daerah memiliki peluang yang leluasa untuk mengatur dan mengurus rumah tangganya sendiri. Tujuan dari desentralisasi tidak lepas dari adanya dorongan terhadap meningkatnya daya guna dan hasil guna penyelenggaraan pemerintahan dalam rangka pelayanan terhadap masyarakat dan pelaksanaan pembangunan.

Jika merunut pada pelaksanaan kebijakan Desentralisasi, saat ini sudah 17 (tujuh belas) tahun Indonesia menerapkan kebijakan desentralisasi melalui Otonomi Daerah. Selama lebih dari satu dasawarsa tersebut, tidak bisa dipungkiri beberapa daerah mengalami kemajuan yang cukup pesat. 
Fatkhuri. Desentralisasi Pendidikan... | 287

Namun demikian, kita juga tidak bisa menegasikan fakta bahwa desentralisasi juga melahirkan berbagai masalah baru. Masalah inilah yang pada akhirnya menjadi penghambat sebagian daerah untuk maju.

Masalah sebagaimana diuraikan di atas lebih menitikberatkan pada belum profesionalnya para penyelenggara negara di tingkat daerah. Dengan adanya pelimpahan wewenang yang diberikan kepada daerah, banyak elit-elit di daerah dengan kekuasaan yang dimiliki melakukan penyalahgunaan wewenang (abuse of power). Penyalahgunaan wewenang yang dimaksud adalah adanya fenomena di mana banyak kepala daerah dan jajarannya terjerat tindak pidana korupsi dalam penyelenggaraan pemerintahan. Korupsi ini lebih berkutat pada masalah penyelewengan dana yang seharusnya untuk kepentingan masyarakat tetapi dikorupsi untuk kepentingan pribadi dan kroni-kroninya. Dalam konteks Pelayanan Publik, Modus Operandi korupsi biasanya dilakukan karena dua faktor. Dari sisi eksternal, adanya keinginan masyarakat untuk memperoleh proses pelayanan yang cepat dalam berbagai urusan seperti pengurusan perijinan dan sejenisnya, sedangkan dari sisi internal lebih menitikberatkan pada adanya fenomena bahwa rentang birokrasi yang panjang dengan sengaja dimanfaatkan oleh oknum-oknum di birokrasi untuk mempersulit dan memperlama proses pengurusan administrasi dan sebagainya sehingga membuka peluang terjadinya tindak pidana korupsi (Fatkhuri, 2017).

Berkaitan dengan korupsi yang dilakukan oleh para Kepala Daerah, sejak tahun 2001 sebagai penanda awal waktu di mana Otonomi Daerah diberlakukan, sudah ratusan kepala daerah yang tersangkut masalah hukum yang disebabkan oleh penyalahgunaan wewenang yang mereka lakukan. Menurut Data Kementerian Dalam Negeri, sampai dengan tahun 2015, sebanyak 343 kepala daerah yang berperkara hukum baik di kejaksaan, kepolisian, mau pun Komisi Pemberantasan Korupsi (KPK), dan ironisnya dari kasus tersebut, sebagian besar karena tersangkut masalah pengelolaan keuangan daerah. Jika ditelisik dari beberapa tahun ke belakang, jumlah kepala daerah berdasarkan Data Kementerian Dalam Negeri dapat diuraikan sebagai berikut: 1) hingga tahun 2010, ada 206 kepala daerah yang tersangkut kasus hukum; 2) 40 kepala daerah pada tahun 2011; 3) 41 kepala daerah pada tahun 2012; dan 23 kepala daerah pada tahun 2013. 
288 | Fatkhuri. Desentralisasi Pendidikan...

(https://nasional.kompas.com). Banyak daerah yang seolah menjadikan wewenang yang dimiliki sebagai peluang untuk memperoleh keuntungan pribadi atau koleganya. Alhasil, desentralisasi yang seharusnya menjadi ruang bagi pemerintah daerah dan masyarakat untuk bahu membahu membangun daerahnya, ternyata dimanfaatkan oleh segelintir elit di daerah untuk mengeruk anggaran negara untuk kepentingan pribadi dan kroni-kroninya. Alih-alih penyelenggara di daerah dapat melakukan percepatan pembangunan pendidikan di daerah, pejabat (elit-elit) pemerintah daerah justru harus terjebak oleh kepentingan pragmatis. Akhirnya, desentralisasi kewenangan tidak semakin mendekatkan fungsi pelayanan kepada masyarakat, tetapi yang terjadi malah sebaliknya semakin memperkaya para penguasa di daerah dan pihak-pihak yang dekat dengan kekuasaan.

Elit-elit yang dimaksud meliputi banyak aktor, seperti Kepala Daerah, Kepala Dinas Pendidikan, Politisi, Kepala Sekolah, dan swasta. Para aktor ini merupakan kelompok orang-orang yang memiliki pengaruh di daerah dan memegang peranan penting baik dalam lini birokrasi pemerintahan maupun di luar pemerintahan. Akibat tindakan korupsi yang dilakukan kelompok ini, mengakibatkan pemenuhan hak-hak rakyat semakin jauh panggang dari api. Akibat sepak terjang para elit, termasuk birokrat, dan politisi di tingkat elit, lembaga pendidikan mengalami kondisi yang memprihatinkan karena tidak menunjukkan performa yang baik (Rosser, 2018). Kondisi inilah yang menjadikan desentralisasi sebagaimana hasil kajian Indonesia Corruption Watch (ICW) telah melahirkan aktor-aktor baru dalam dunia korupsi. Dalam kajiannya, ICW menyimpulkan bahwa desentralisasi pendidikan telah memunculkan aktor-aktor korupsi pendidikan baru, yakni kepala dinas pendidikan beserta jajarannya. Hal ini terjadi karena rendahnya partisipasi publik dalam kontrol kewenangan dinas pendidikan daerah dalam penetapan kebijakan dan anggaran pendidikan daerah. Kebijakan dan pengelolaan anggaran pendidikan daerah hanya dikuasai oleh pejabat birokrasi pendidikan daerah. (https://www.icw.or.id).

Berkaitan dengan praktik menyimpang dalam penyelenggaraan desentralisasi di bidang pendidikan, Indonesia Corruption Watch (ICW) mencatat bahwa sejak tahun 2005 sampai dengan 2016, sudah ada sebanyak 425 kasus korupsi, dan dari jumlah tersebut sebanyak 214 (50,35 persen) 
Fatkhuri. Desentralisasi Pendidikan... | 289

kasus terjadi di dinas pendidikan. Objek korupsi pendidikan diantaranya meliputi Dana Alokasi Khusus (DAK), sarana dan prasarana sekolah, dana BOS hingga infrastruktur sekolah serta dana buku (http://www.tribunnews.com). Hasil kajian ICW tersebut juga menunjukkan sepanjang tahun 2005 sampai dengan 2016, sarana dan prasarana menjadi sumber dana yang paling banyak dikorupsi dengan nilai total Rp. 542,5 Milyar. (https://katadata.co.id). Selanjutnya, Global Corruption Barometer pada tahun 2013 juga merilis data yang tidak jauh berbeda. Dalam studinya, sebanyak 49 persen responden merasakan sistem pendidikan telah mengalami korupsi dan sangat korup, dan 21 persen responden menyatakan pernah memnerikan suap saat berhubungan dengan layanan pendidikan (Niken Ariati, 2016).

Data di atas mengkonfirmasi bahwa desentralisasi telah melahirkan banyak aktor korupsi dan umumnya melibatkan elit-elit di daerah. Fenomena terbaru terkait tindak pidana korupsi dana pendidikan yang melibatkan kepala daerah adalah kasus penetapan tersangka terhadap Bupati Sabu Raijua, Marthen Dira Tome Nusat Tenggara Timur pada tahun 2016. Marthen yang notabene mantan Kepala Subdinas PLS Dinas Pendidikan dan Kebudayaan Dikbud Provinsi NTT dan pejabat pembuat komitmen (PPK) ditangkap oleh penyidik Komisi Pemberantasan Korupsi (KPK) atas tuduhan kasus dugaan korupsi dana pendidikan luar sekolah (PLS) di Nusa Tenggara Timur. Dana PLS berasal dari Dinas Pendidikan dan Kebudayaan NTT tahun 2007 yang diambil dari dana APBN (kompas.com, 2016). Selain melibatkan kepala daerah, korupsi juga melibatkan pejabat di daerah. Misalnya, baru-baru ini SW Katiandagho, Mantan Kepala Dinas Pendidikan dan Olah Raga Kabupaten Kepulauan Sitaro ditetapkan sebagai tersangka oleh Kejaksaan Tinggi (Kejati) Sulawesi Utara (Sulut). (http://manado.tribunnews.com). Penetapan tersangka Mantan Kepala Dinas Pendidikan ini karena telah melakukan penyalahgunaan wewenang dengan mengkorupsi dana pendidikan. Tersangka diduga telah menyalahgunakan wewenang sebagai kepala dinas pendidikan dengan melakukan pungutan sebesar 12 persen dari dana DAK tahun 2012 yang diterima setiap sekolah, dengan total dana yang dikumpulkan sebesar Rp. 924.092 .200 (http://manado.tribunnews.com). 
Fakta di atas menunjukkan bahwa penyelenggaraan desentralisasi belum menyentuh upaya menyelesaikan berbagai masalah pendidikan yang dihadapi masyarakat di daerah. Akar masalah pendidikan di daerah pada umumnya adalah pada pemerataan akses pendidikan dan layanan pendidikan yang masih jauh dari kata "berkualitas". Alih-alih membuat terobosan untuk melakukan percepatan pembangunan pendidika, para elit di daerah justru menggunakan wewenang yang dimilikinya untuk memperkaya diri sendiri. Tidak bisa dihindari, korupsi yang dilakukan elit-elit di daerah pada akhirnya menjadi hambatan bagi sebagian daerah di Indonesia dalam melakukan upaya pemerataan akses dan perbaikan mutu layanan di bidang pendidikan. Terkait masalah korupsi ini, Hallak dalam Handayani (2009) menguraikan bahwa "di negara-negara berkembang, termasuk Indonesia korupsi sering kali merupakan masalah endemik seluruh masyarakat, dan sektor pendidikan merupakan salah satu sektor yang termasuk kategori rentan terhadap korupsi, karena relatif besarnya anggaran pendidikan, sehingga cenderung memberi peluang untuk praktik korupsi yang semakin besar pula" (Titik Handayani, 2009). Besarnya anggaran pendidikan bahkan yang bersumber dari APBN tanpa dibarengi dengan proses pengawasan yang ketat menyebabkan perilaku semakin menggurita. Korupsi yang melibatkan kepala daerah dan para pejabat di daerah selama ini sangat jelas menyebabkan kondisi dunia pendidikan di daerah semakin terpuruk.

Jika ditelaah lebih mendalam, penyebab adanya tindakan korupsi di daerah karena dua alasan berikut ini:

Pertama, bagi kepala daerah, korupsi dilakukan lebih karena kepentingan politik. Tingginya ongkos politik menyebabkan para kepala daerah harus mencari sumber pendanaan dengan cara ilegal. Modus yang dilakukan oleh kepala daerah bermacam-macam, salah satunya dengan menyelewengkan dana APBN yang ditransfer ke daerah. Tindakan lain yang umumnya dilakukan oleh kepala daerah dalam rangka mencari dana untuk kepentingan pribadi adalah dengan "memaksa" pejabat dinas pendidikan menyetor sejumlah uang untuk mendapatkan jabatan kepala dinas. Realitas inilah yang menyebabkan banyak terjadi penyelewengan dana di daerah. Di samping karena untuk memperkaya diri sendiri atau orang lain, modus 
korupsi juga dilakukan untuk membangun, mempertahankan dan memperluas kekuasaan dalam kompetisi politik daerah (Titik Handayani, 2009).

Kedua, bagi para pejabat, seperti Kepala Dinas di lingkungan Pemerintah Daerah (Dinas Pendidikan baik provinsi maupun Kabupaten/Kota), korupsi dilakukan karena tekanan atasan (kepala daerah) atau kepentingan promosi jabatan sebagaimana diuraikan di atas. Kepala Dinas umumnya akan menyelewengkan dana untuk kepentingan mengamankan jabatan yang dimiliki, atau untuk kepentingan kenaikan jabatan. Hal ini juga terjadi pada pejabat pada level lebih rendah hingga kepala sekolah. Jika tak memberi setoran atau meloloskan kepentingan atasannya, pejabat tersebut bisa dirotasi atau jabatannya dicopot. Semua biaya untuk mendapatkan kekuasaan dan jabatan ini menjadi alasan mereka korupsi saat menjabat, agar bisa mengembalikan dana yang digunakan untuk membeli jabatan dan kekuasaan dan menumpuk kekayaan (http://stranasppk.bappenas.go.id/ironikorupsi-pendidikan.html). Kasus terbaru berkaitan dengan suap dalam rangka promosi jabatan seperti yang terjadi pada Bupati Klaten, Sri Hartini. Dalam salah satu kasus korupsi yang menjerat Sri Hartini, dia disangkakan menerima uang gratifikasi dari kepala sekolah SMP dan SMA dengan nilai uang Rp 3,162 miliar untuk kepentingan promosi dan mutasi kepala Sekolah(http://regional.kompas.com).

\section{Politik Kekuasaan sebagai hambatan Pembangunan Pendidikan}

Desentralisasi pendidikan merupakan sebuah usaha yang bertujuan untuk meningkatkan mutu layanan dan kinerja pendidikan, baik pemerataan, kualitas, relevansi dan efisiensi pendidikan. Namun, faktanya banyak daerahdaerah belum beranjak dari masalah yang menggerogoti efektifitas perjalanan roda pemerintahan. Selain karena masalah penyelenggara negara di daerah yang melakukan tindakan korupsi, kuatnya pengaruh kekuasaan politik penguasa di daerah menjadikan layanan pendidikan tidak dapat berjalan sebagaimana mestinya. Kuatnya cengkeraman politik penguasa lokal mengakibatkan prosedur dan peraturan seringkali tidak berjalan, yang pada gilirannya menjadi penyebab terjadinya pelayanan pendidikan yang terhambat. Dalam banyak hal, pengaruh politik seringkali menjadi penyebab 
sistem tidak dapat bekerja, yang ujung-ujungnya kepentingan rakyat yang dikorbankan.

Berkaitan dengan kuatnya pengaruh politik, dapat dilihat pada fenomena sebagaiana diuraikan berikut:

Pertama, banyak kepala daerah atau pejabat daerah memanfaatkan posisi yang dimiliki untuk membangun jejaring politik. Mereka akan membangun pengaruh dan dukungan kepada lembaga-lembaga strategis di bidang pendidikan seperti Sekolah. Sekolah seringkali tidak berdaya ketika berhadapan dengan penguasa. Khusus untuk Sekolah-Sekolah Negeri, pengaruh tersebut akan semakin kuat sebab kepala daerah melalui kepala dinas pendidikan dapat kapan saja mencopot jabatan kepala Sekolah jika tidak mematuhi perintah mereka. Lembaga pendidikan seperti Sekolah sengaja dimanfaatkan sebagai simpul untuk membangun kekuatan politik. Saat menjelang Pilkada biasanya merupakan momentum yang sangat penting bagi kepala daerah yang akan maju kembali dalam Pilkada. Dalam konteks ini kepala daerah sebagain calon incumbent melakukan mobilisasi massa melalui kepala Sekolah. Para kepala Sekolah akan diminta menjadi Tim Sukses Incumbent untuk membantu menggalang dukungan melalui guru dan masyarakat luas. Kepala Sekolah dan guru yang semestinya harus netral dan profesional dalam menjalankan tugasnya, pada akhirnya harus rela meninggalkan tugas utamanya. Kepala Sekolah dan guru tidak berdaya manakala harus menolak permintaan ini, sebab jabatan akan menjadi sasarannya.

Fenomena kuatnya pengaruh politik penguasa lokal juga dapat dilihat dari adanya fenomena pelaksanaan Ujian Nasional (UN). Beberapa kepala daerah melakukan intervensi yang terlalu jauh sehingga Sekolah/Madrasah tidak dapat berperan secara optimal. Contoh bentuk intervensi yang dilakukan dapat dilihat dari kasus yang terjadi di daerah Pare-Pare, Sulawesi Selatan. Sebagaimana yang dinyatakan oleh Sekjen Federasi Guru Independen Indonesia (FGII), Iwan Hermawan bahwa momentum pelaksanaan UN akan seringkali dimanfaatkan oleh aparat daerah untuk menekan guru. UN seringkali dijadikan celah bagi aparat pemerintah daerah untuk memaksa Sekolah untuk memberikan yang terbaik, meskipun harus menabrak regulasi. Jika UN gagal maka kepala sekolah dimutasi. (http://www.tribunnews.com). 
Kedua, relasi politik penguasa tidak berhenti pada Sekolah. Di tingkat yang lebih tinggi, dalam rangka membangun simpul-simpul kekuatan politik, kepala daerah akan mengangkat orang-orang yang diharapkan dapat mendukung kekuatan politik mereka. Kasus ini bukan saja terjadi pada lembaga-lembaga strategis yang secara hirarki berada dalam wewenangnya. Namun, keberadaan lembaga-lembaga penting lainnya yang berkaitan dengan sektor pendidikan juga akan dimanfaatkan untuk menjadi political lingkage bagi kepala daerah. Misalnya, keberadaan Badan Akreditasi Provinsi Sekolah/Madrasah (BAP-S/M) sebagai lembaga Independen kepanjangan tangan dari Badan Akreditasi Nasional Sekolah/Madrasah (BAN-S/M) pemerintah pusat, tidak lepas dari aroma politik di tingkat lokal. Dalam proses seleksi atau pengangkatan anggota bahkan sampai Ketua dan Sekretaris BAP$S / M$, seringkali sarat dengan muatan politik. Gubernur umumnya akan mengangkat anggota dari orang-orang yang memiliki kedekatan dengan dirinya. Di sinilah independensi Badan Akreditasi Sekolah/Madrasah sebagai lembaga penjaminan mutu pendidikan menjadi abu-abu. Di satu sisi eksistensi lembaga ini merupakan kepanjangan tangan dari lembaga akreditasi di tingkat pusat, tetapi di sisi lain peraturan memberikan wewenang kepada Gubernur untuk membentuk BAP-S/M sehingga hal rawan penyalahgunaan wewenang (Peraturan Menteri Pendidikan dan Kebudayaan Nomor 13 tahun 2018 tentang Badan Akreditasi Nasional Sekolah/Madrasah (BAN-S/M) dan Badan Akreditasi Nasional Pendidikan Anak Usia Dini dan Non Formal (BAN-PAUD dan PNF).

Kuatnya pengaruh politik Gubernur pada lembaga ini tentunya dapat mengganggu netralitas dan independensi institusi Badan Akreditasi Sekolah/Madrasah. Bisa saja dalam menjalankan perannya, lembaga ini kemudian menjadi bias politik. Sisi positif dari pengaruh politik kepala daerah ini sebenarnya bisa menjadi daya dorong untuk menguatkan lembaga ini semakin kuat. Hal ini terjadi manakala pendanaan untuk kegiatan operasional dan pelaksanaan akreditasi dapat diberikan oleh kepala daerah. Namun demikian, berdasarkan data yang ada, selama ini kecil sekali persentase kepala daerah yang memberikan alokasi anggaran APBD untuk mendukung pelaksanaan akreditasi di daerah. Dengan demikian, percepatan pembangunan pendidikan hanyalah slogan semata, sementara keseriusan pemerintah daerah dalam pembangunan pendidikan bisa dikatakan tidak ada. 
294 | Fatkhuri. Desentralisasi Pendidikan...

\section{Kesimpulan dan Saran}

Pelaksanaan desentralisasi pendidikan di Indonesia belum menunjukkan hasil yang memuaskan. Studi ini menguraikan bahwa hambatan yang dihadapi pemerintah daerah lebih menitikberatkan pada faktor internal, yaitu korupsi dan pengaruh politik kekuasaan, dan kuatnya pengaruh politik penguasa di tingkat lokal. Faktor pertama mengindikasikan bahwa Korupsi para kepala daerah dan pejabat publik di daerah dilakukan dengan menyalahgunakan wewenang melalui pemanfaatan anggaran negara. Besarnya anggaran pemerintah melalui APBN tidak bisa dioptimalisasi untuk peningkatan layanan pendidikan. Para Kepala Daerah dan elit-elit daerah justru terjebak pada kepentingan pragmatisme untuk menangguk keuntungan pribadi. Faktor kedua menggambarkan kuatnya pengaruh politik penguasa di tingkat lokal. Dengan kekuasaan yang dimiliki, para Kepala Daerah seakan seperti raja-raja kecil yang harus dipatuhi oleh semua bawahannya. Besarnya cengkeraman politik di tingkat lokal yang secara berjenjang mengalir ke bawah mengakibatkan Sekolah dan lembaga pendidikan lainnya tidak maksimal dalam menjalankan tugas dan tanggung jawabnya.

Terobosan yang perlu dilakukan adalah perlunya penguatan peran civil society untuk memperkuat mekanisme check and balance penyelenggaraan pemerintahan di tingkat lokal. Civil society dapat memerankan diri sebagai agen of control terhadap tata kelola pemerintah. Dengan demikian, praktikpraktik yang menyimpang dan merugikan dalam penyelenggaraan pemerintahan terutama di sector pendidikan dapat diminimalisir dengan efektif.

\section{Daftar Pustaka}

\section{Buku}

Bahl, Roy. 2009. Promise and reality of fiscal decentralisation, in Shinici Icimura and Roy Bahl (Eds.), Decentralization Policies in Asian Development, World Scientific. 
Fatkhuri. Desentralisasi Pendidikan... | 295

Jones, David Seth. 2008. Budgetary Reforms in Southeast Asia, in Evan M. Berman and Jack Rabin (Eds.) Encylcopedia of Public Administration and Public Policy, Volume 1.

Rosser, Andrew. 2018. Beyond access: Making Indonesia's education system work, The Lowy Institute, Victoria State Government, Australia.

Tharenou, Phyllis dkk. 2007. Management Research Methods, Cambridge University Press, UK.

\section{Jurnal}

Fatkhuri, 2017. Korupsi Dalam Birokrasi dan Strategi Pencegahannya, Jurnal Ilmiah Manajemen Publik dan Kebijakan Sosial - Vol. 1 No. 2, hal 6576

Handayani, Titik. 2009. Korupsi dan Pembangunan Pendidikan Di Indonesia, Jurnal Kependudukan Indonesia, Vol. IV, No.2.

Purwanto, Nurtanio Agus, 2008. Pengaruh Politik Dalam Bidang Pendidikan, Jurnal Manajemen Pendidikan, No. 02/Th IV/Oktober.

Supriyadi, Ujang Didi. 2009. Pengaruh desentralisasi pendidikan dasar terhadap kualitas pendidikan di kabupaten Jembrana provinsi bali, Jurnal Kependidikan, Tahun XXXIX, Nomor 1, Mei 2009,:41

Winingsih, Lucia H. (tanpa tahun). Desentralisasi Pendidikan Di Indonesia: Sebuah Reviu A Review On Educational Decentralization In Indonesia, Pusat Penelitian Kebijakan, Badan Penelitian dan Pengembangan, Kementerian Pendidikan dan Kebudayaan

\section{Informasi Internet/Koran online}

http://news.metrotvnews.com/politik/IKYM5ejK-menteri-pendidikan-tak-inginsekolah-gratis-jadi-komoditas-politik, diakses 5 Februari 2018 http://www.dpr.go.id/berita/detail/id/18840/t/Isu+Pendidikan+Jangan+Hany a+Untuk+Kepentingan+Jualan+Pilkada, diakses 9 Februari 2019. https://pisaindonesia.wordpress.com/, diakses 5 Februari 2018. 
296 | Fatkhuri. Desentralisasi Pendidikan...

https://www.kemdikbud.go.id/main/blog/2016/12/peringkat-dan-capaian-

pisa-indonesia-mengalami-peningkatan, diakses 5 Februari 2018. http://nasional.kompas.com/read/2015/02/04/21114211/Mendagri.343.Kepal

a.Daerah.Tersangkut.Kasus. Hukum, diakses 7 Februari 2018.

https://www.antikorupsi.org/id/news/analisis-5-tahun-pemberantasankorupsi-pendidikan-2004-2009, diakses 10 Februari 2018.

http://www.tribunnews.com/nasional/2017/04/24/icw-ungkap-korupsi-di-

dunia-pendidikan-dinas-pendidikan-urutan-teratas, diakses 10 Februari 2018.

http://nasional.kompas.com/read/2016/11/15/17173431/bupati.sabu.raijua. marthen.dira.kaget.ditahan.kpk, diakses 27 Februari 2018.

http://manado.tribunnews.com/2018/02/20/usai-diperiksa-mantan-kadisdiksitaro-ini-langsung-dijebloskan-ke-rutan-malendeng, diakses 25 Februari 2018.

http://stranasppk.bappenas.go.id/ironi-korupsi-pendidikan.html, diakses 11 Februari 2018.

http://www.tribunnews.com/nasional/2011/06/18/pemerintah-daerahintervensi-guru-dan-kepala-sekolah http://regional.kompas.com/read/2017/08/28/17164981/rincian-suap-rp128-miliar-yang-diterima-bupati-klaten, diakses 27 Februari 2018. https://katadata.co.id/infografik/2016/05/23/korupsi-sektor-pendidikanrugikan-negara-rp-13-triliun, diakses 27 Februari 2018.

\section{Laporan Pemerintah/Undang-Undang}

Ariati, Niken. 2016. Pencegahan Korupsi Sektor Kesehatan dan Pendidikan, Fungsional Direktorat Peneli6an dan Pengembangan Deputi Pencehagan, KPK RI.

Country Note - Results from PISA 2015. 2016. Programme for International Student Assessment Results Form PISA 2015, OECD.

Undang-Undang Nomor 32 tahun 2004 tentang Pemerintahan Daerah Undang-Undang Nomor 23 tahun 2014 tentang Pemerintahan Daerah 
Permendikbud Nomor 13 tahun 2018 tentang Badan Akreditasi Nasional Sekolah/Madrasah (BAN-S/M) dan Badan Akreditasi Nasional Pendidikan Anak Usia Dini dan Non Formal (PAUD-PNF). 